\title{
Ghrelin Overektomi Yapılmış Sıçanlarda Gastrik İnflamasyonu Düzeltir
}

\section{Ghrelin Alleviates Gastric Inflammation in Ovariectomized Rats}

\author{
Esra Bihter GÜRLER ${ }^{1} \mathbb{D}$, Özlem Tuğçe çiLingiR KAYA ${ }^{\mathbb{D}}$, Dilek ÖZBEYLi ${ }^{3}$ \\ 1 İstanbul Atlas Üniversitesi Tıp Fakültesi, Fizyoloji AD, İstanbul, Türkiye \\ 2 Marmara Üniversitesi Tıp Fakültesi Histoloji ve Embriyoloji AD, İstanbul, Türkiye \\ ${ }^{3}$ Marmara Üniversitesi, Sağlık Meslek Yüksekokulu, Patoloji Laboratuvar Teknikleri Bölümü, İstanbul
}

Öz.

Amaç: illerleyen yaş ve mide hastalıkları arasında bir ilişki vardır. Bu çalışmanın amacı, ghrelinin overektomize sıçanlarda mide morfolojisi üzerindeki etkilerini değerlendirmektir.

Materyal ve metod: Ketamin-klorpromazin anestezisi altında (100 mg / kg, 0,75 mg / kg), SpragueDawley sıçanlarına $(n=12)$ çift taraflı overektomi, kontrol grubuna taklit cerrahi $(\mathrm{G} 1)$ uygulandı $(n=$ 6). Ameliyattan dört hafta sonra, overektomili sıçanlarının yarısı (G3) 4 hafta boyunca intraperitoneal olarak ghrelin (1 mg / kg / hafta) ile tedavi edildi, kontrol grubuna (G2) serum fizyolojik uygunlandı. 8. hafta sonunda kardiyak ponksiyon ile ötenazi yapılarak östrojen düzeyi ölçüldü. Mide dokusunda ışık ve taramalı elektron mikroskopu ile histolojik inceleme yapılmıştır.

Bulgular: 2 ay sonunda $G 2$ ve $G 3$ gruplarında overektomi ile artan $(p<0,001)$ vücut ağırlıkları, ghrelin (G3) ile değişmedi. Overektomi gruplarında (G2 ve G3) serum östradiol düzeyi değişmiş gonadal hormon durumu doğrulayacak şekilde azaldı $(p<0,05)$. Overektomi yapılmış olan kontrol grubunda (G2) vaskülar dilatasyon ve dejenerasyonla karakterize hasar izlenirken ghrelin grubunda (G3) taklit cerrahi grubuna (G1) benzer olarak düzenli morfolojide apikal mukus hücreleri ve gastrik pitler gözlendi.

Sonuç: Sonuç olarak menopoz sonrası erken dönemde hafif gastrik hasarın ghrelin tedavisi ile azaldığı ve bu alanda daha fazla araştırmaya intiyaç duyulduğu görülmektedir.

Anahtar Kelimeler: Ghrelin, İnflamasyon, Postmenopoz, Gastrik mukoza

Abstract

Background: There is a link between aging and gastric diseases. The aim of this study was to evaluate the effects of ghrelin on gastric morphology in ovariectomized rats.

Materials and Methods: Under ketamine-chlorpromazine anesthesia $(100 \mathrm{mg} / \mathrm{kg}, 0.75 \mathrm{mg} / \mathrm{kg}$ ), Sprague-Dawley rats $(n=12)$ underwent bilateral ovariectomy, while control group (G1) had shamsurgery $(n=6)$. Four weeks after surgery, half of ovariectomized rats (G3) were treated intraperitoneally with ghrelin ( $1 \mathrm{mg} / \mathrm{kg} /$ week) for 4 weeks, while others (G2) were not treated. Rats were euthanized by cardiac puncture at the end of 8th weeks, and serum levels of estradiol were measured. Gastric tissue was analyzed with light and scanning electron microscopy.

Results: Increased body weights in ovariectomized (G2 and G3) rats $(p<0.001)$ recorded at the end of 2 months was not changed with ghrelin. In ovariectomized groups (G2 and G3) serum estradiol levels were reduced $(p<0.05)$ verifying altered gonadal hormone status. Apical mucus cells and gastric pits were observed in regular morphology in sham group while vascular dilatation and degeneration was observed in ovariectomized rats (G2 and G3), whereas in the ghrelin group (G3) it was generally observed similar to sham group (G1).

Conclusion: In conclusion, mild dyslipidemia and hepatic degeneration in early post-menopausal period appear to be attenuated by ghrelin treatment, and it is required further investigations.

Key words: Ghrelin, Inflammation, Postmenopause, Gastric mucosa
Sorumlu Yazar / Corresponding Author

Dr. Öğr. Üyesi Esra Bihter GÜRLER

İstanbul Atlas Üniversitesi Tıp

Fakültesi Fizyoloji AD.

Anadolu Cad. No. 40

Kağıthane/Istanbul

e-mail: ebgurler@gmail.com

Geliş tarihi / Received:

16.12.2020

Kabul tarihi / Accepted:

19.08.2021

DOI: $10.35440 /$ hutfd. 841915 


\section{Giriş}

Osteoporoz; başlıca östrojen eksikliğinin neden olduğu kemik kütlesinin kaybı ile oluşan, ağrı ve hareket kabiliyetinde kısıtlılık yaratan, kemik yapım/yıkım oranının bozulduğu, kemiğin sık görülen metabolik bir hastalığıdır $(1,2)$. Hastalığın menopoz sonrası görülen formunda ise östrojen eksikliği ana unsur olarak rol almaktadır.

Atrofik gastrit, mukozal hasar sonucu midede kalıcı bir hipoklorhidriye yol açan ve yaşla artan bir durumdur (3). Benzer olarak Helicobacter pylori proliferasyon yoğunluğu hem fundus hem de antrumda menopozdaki kadınlarda daha yüksek bulunmuştur (4). Helicobacter pylori ile osteoporoz $(5,6)$ ve atrofik gastrit ile osteoporoz $(7,8)$ arasında pozitif ve negatif ilişkiler gösteren çalışmalar mevcuttur. Pepsinojen I serum düzeyi ile kemik mineral yoğunluğu arasında lineer bir ilişki olduğunu gösteren bir pernisiyöz anemi çalışması da literatürde görülmektedir (9).

Ghrelin 1999 yılında keşfedilmiş, 28 aminoasitli başlıca midenin korpus ve pilor bölgesinden salgılanan bir hormondur. Ghrelin pek çok fizyolojik fonksiyonunu ghrelin öncülü olan proghrelinin açillenmesi ile olgunlaşmış açil ghrelin formuyla yapar (10). Yapılan çalışmalar arasında endojen ghrelinin gastrik asit sekresyonunu ve gastrik motiliteyi arttırdığı rapor edilmiştir (11). Öte yandan çeşitli çalışmalarda gastrointestinal sistemin inflamatuvar hastalıklarında ghrelinin anti-inflamatuvar ve anti-oksidan etkileri ile koruyucu ve tedavi edici olduğu gösterilmiştir. Mide kanserli olguların patolojik örnekleriyle yapılan bir immünohistokimyasal çalışmada mide dokusunda bu hormonun varlığı tespit edilememiştir (12). $\mathrm{Bu}$ çalışmada overektomili sıçanların mide dokusundaki değişikliklerin histolojik olarak incelenmesi ve ekzojen ghrelin tedavisinin etkisinin araştırılması amaçlanmıştır.

\section{Materyal ve Metod Hayvanlar}

Bu çalışma için Marmara Üniversitesi Hayvan Deneyleri Yerel Etik Kurulundan onay alındı (057.2016.mar). Marmara Üniversitesi Deney Hayvanları Merkezinden temin edilen, 250-300 gr ağırlığındaki 18 adet dişi Sprague Dawley sıçan rastgele olarak (kapalı zarf usulü ile) seçilerek gruplandırıldı. Ortam sıcaklığı (20-22 으) ve nemi (\%65-70) korunan ortamda, kafeslerde rahat hareket edebilecekleri şekilde üçerli olarak yerleştirilen sıçanlara, 12 saat/12 saat gündüz/gece ışık uygulandı. Deney süresince yem ve su tüketimleri ad libitum olarak sağlandı.

\section{Deney Protokolü ve Cerrahi Yöntem}

Taklit cerrahi yapılan grup $(\mathrm{G} 1 ; \mathrm{n}=6)$ dışındaki tüm gruplara (G2, G3; n=6/grup) overektomi (OVT) yapıldı. OVT uygulaması, anestezi altında (Ketamin 100 mg/kg ve klorpromazin $5 \mathrm{mg} / \mathrm{kg}$; i.p.) paramedyan kesi ile ulaşılan over ligamentlerinin ligatürle bağlanmasının ardından overlerin eksizyonu ile gerçekleştirildi. Ardından karın duvarı kapatılarak, $1 \mathrm{ml} / \mathrm{kg}$ serum fizyolojik s.c. olarak verildi. Taklit cerrahi grubundaki hayvanlarda ise yine paramedyan kesi ile overlere ulaşıldı ve bir işlem yapılmadan doku süture edildi. OVT yapılan hayvanlar rastgele 2 gruba (G2 ve G3) ayrıldı. Dört haftalık derlenme süresinin ardından başlanan tedaviler, 8 . haftanın sonuna kadar sürdürüldü. $G 2$ ve G3 gruplarında bulunan overektomi yapılmış sıçanlara 4 hafta boyunca; serum fizyolojik (G1; $1 \mathrm{ml} / \mathrm{kg}$ ) ve distile suda $1 \mathrm{mg} / \mathrm{ml}$ olarak çözülen ghrelin ( Sigma,G8903, St Louis, MO; $1 \mathrm{mg} / \mathrm{kg} /$ hafta i.p.) deney hayvanlarına (G2) haftada bir doz olacak şekilde uygulandı. (13-15) (Şekil 1).

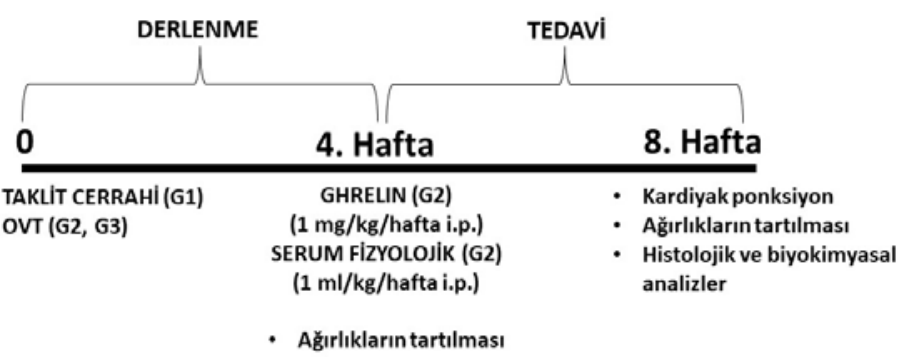

Şekil 1. Deney Protokolü

8. hafta sonunda sıçanlar anestezi altında (Ketamin 100 $\mathrm{mg} / \mathrm{kg}$ ve klorpromazin 3-5 mg/kg; i.p.) kardiyak ponksiyon ile ötanazi edildi. Kan örnekleri alınarak 10000 rpm'de $+4{ }^{\circ} \mathrm{C}$ 'de santrifüje edildi. Ayrılan serum örnekleri östrojen düzeylerinin değerlendirilmesi için biyokimyasal analiz gününe kadar $-80^{\circ} \mathrm{C}$ 'de muhafaza edildi.

\section{Biyokimyasal Analiz}

Kan numuneleri toplandıktan sonra 10 dakika süreyle 10000 rpm'de santrifüje edilerek elde edilen serum örnekleri $-80^{\circ} \mathrm{C}$ de saklandı. Serum örneklerinde östrojen (ng/kg) ticari ELISA (Enzyme-Linked Immuno Sorbent Assay) kit (Sun Red, Şangay, Çin) kullanarak ve üretici tarafından verilen talimatlara uygun şekilde yapıldı.

Histolojik analizler

\section{Işık Mikroskopik Preparasyon}

Işık mikroskopik incelemeler amacıyla, mide dokusundan alınan örnekler \%10 nötral formalin solüsyonunda immersiyon yöntemi ile tespit edildi. Yükselen alkol serilerinden (\%70, \%90, \%96, \%100) geçirilerek dehidrate edilen dokular, ksilen ile saydamlaştırıldı ve parafine gömülerek bloklandı (Leica TP1020 ve EG1150H+C). Yaklaşık 5 um kalınlığında alınan kesitler (Leica RM2125RT), histopatolojik değerlendirmeler için hematoksilen ve eozin (H\&E) ile boyanarak, kamera eklentisi (Olympus DP72, Tokyo, Japonya) bulunan ışık mikroskobunda (Olympus BX51, Tokyo, Japonya) incelendi ve fotoğraflandı.

\section{Taramalı Elektron Mikroskopik Preparasyon}

Taramalı elektron mikrosokopik incelemeler için mide dokularından alınan örnekler \%4 glutaraldehit $(0,1 \mathrm{M}$ fosfat tamponlu ve $\mathrm{pH} 7,4)$ solüsyonu ile 4 saat fikse edildi ve $\% 1$ $\mathrm{OsO}_{4}$ ile 1 saat post-fiksasyon yapıldı. Yükselen alkol serileri (\%70, \%90, \%96, \%100) ile dehidrate edilen dokular, amilasetat ile inkübe edildikten sonra kritik nokta kurutucusu ile (Bio-Rad E 3000) kurutuldu ve altın ile kaplandı. 
Örnekler taramalı elektron mikroskobu ile incelenerek (Jeol 5200 JSM, Tokyo, Japonya) fotoğraflandı.

\section{İstatistiksel Yöntem}

Parametrik olmayan verilerin analizi Kruskal Wallis ve Student's t-testi takip eden post hoc Mann Whitney $U$ analizi ile yapıldı ve $p<0,05$ istatistiksel olarak anlamlı kabul edildi. Bulgular GraphPad Prism 6.0 ile değerlendirildi ve ortalama \pm standart hata şeklinde ifade edildi.

\section{Bulgular}

Overektomi sonrası tüm hayvanların $(G 2, G 3)$ ağırlıklarında anlamlı bir artış görüldü $(p<0,001)$. Ancak ghrelin uygulaması ile hayvanların (G3) ağırlıklarında anlamlı bir değişiklik olmadı (Şekil 2).

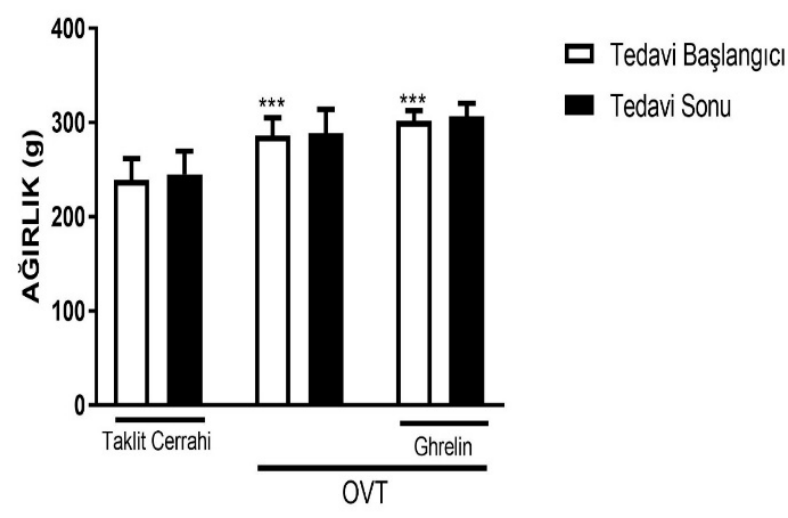

Şekil 2. Hayvanların ağırlıkları

* Ortalama \pm standart hata, $n=6-12$ sıçan/grup; ${ }^{* * *} p<0,001$ taklit cerrahi kontrol grubuna göre (G1; taklit cerrahi, G2; OVT+serum fizyolojik, G3; OVT +ghrelin)

8. haftanın sonunda $\mathrm{G} 2$ ve $\mathrm{G} 3$ gruplarında serum östrojen düzeyi taklit cerrahi grubuna göre anlamlı olarak düşmüştür ( $p<0,01$; Şekil 3).

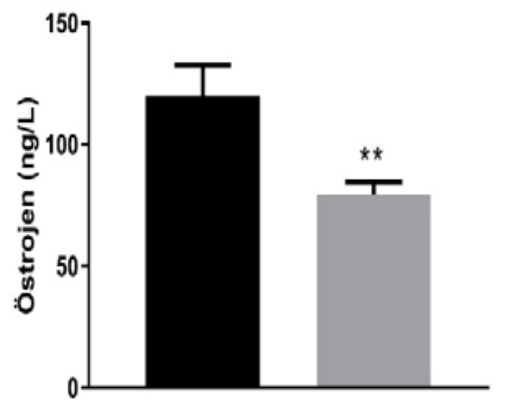

8. Hafta Taklit Cerrahi

8. Hafta OVT

Şekil 3. Overektomi sonrası 8. haftada serum östrojen düzeyi

* Ortalama \pm standart hata, $n=6-12$ sıçan/grup; ${ }^{*} p<0,01$ taklit cerrahi kontrol grubuna göre

Taklit cerrahi (G1) kontrol grubunda, gastrik pitlerle birlikte yüzey epiteli ve glandular epitel düzenli morfolo- jide gözlendi (Şekil 4A). G2 grubunda, hafif vasküler dilatasyon ve bazı glandular hücrelerde hafif genişleme ve dejenerasyon gözlenirken, yüzey mukus hücreleri ve gastrik pitlerde hafif hasar gözlendi (Şekil 4B). G3 grubunda, oldukça düzgün yüzey epiteli ve hafif glandular hücre hasarı görüldü (Şekil 4C).
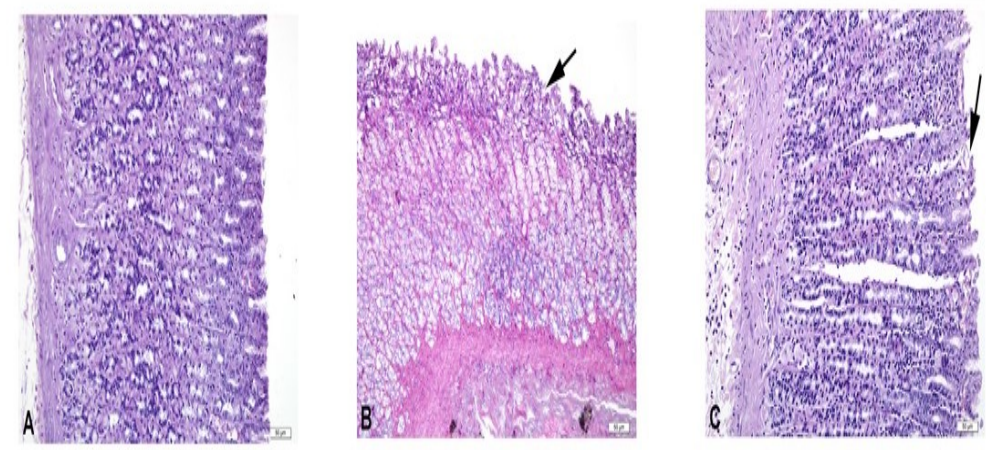

Şekil 4. Deney gruplarına ait temsili resimler (Işık Mikroskobu)

Taklit cerrahi (G1) kontrol grubunda (A) düzenli morfolojide gastrik pitleri olan yüzey epiteli ve glandular epitel; $G 2$ grubunda (B) yüzey mukus hücrelerinde (ok) ve glandular hücrelerde (okbaşı) hafif hasar, hafif inflamatuvar hücre infiltrasyonu (i); G3 grubunda (C), oldukça düzgün yüzey epiteli (ok) ve glandular epitelde hafif hasar (ok başı).

Mide luminal yüzeyindeki topografik değişiklikler taramalı elektron mikroskobu ile değerlendirildi. Taklit cerrahi (G1) grubunda düzenli morfolojide apikal mukus hücreleri ve gastrik pitler gözlendi (Şekil 5A). G2 grubunda hafif düzeyde apikal yüzey hücrelerinde deskuamasyon ve bazı alanlarda lamina proprianın açığa çıktığı gözlendi (Şekil 5B). G3 grubunda genel olarak düzenli morfolojide luminal mide mukoza yapısı, yer yer yüzey mukus hücrelerinde deskuamasyon gözlendi (Şekil 5C).
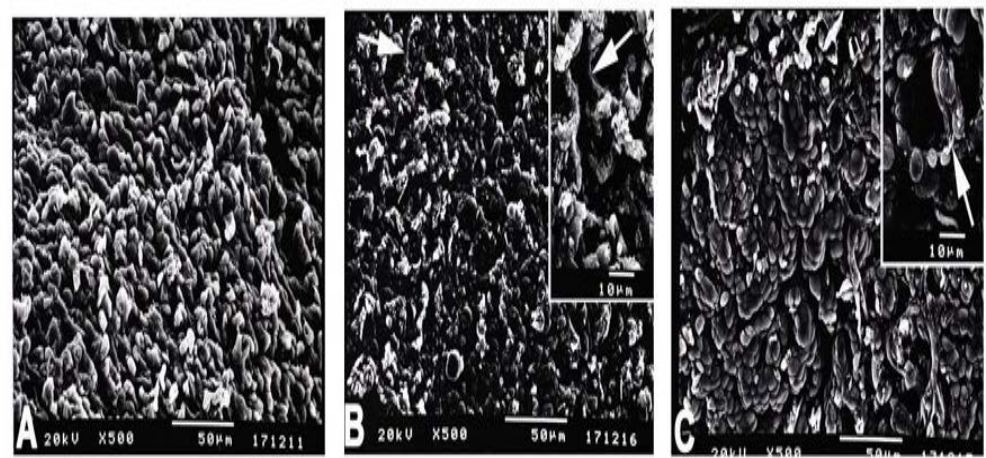

Şekil 5. Deney gruplarına ait temsili resimler (SEM) Deney gruplarının mide örneklerine ait temsili taramalı elektron mikrografları görülmektedir. G1 grubunda (A) düzenli morfolojide apikal mukus hücreleri ve gastrik pitler, G2 grubunda (B) hafif düzeyde apikal yüzey hücrelerinde deskuamasyon (ok) ve G3 grubunda (C) genel olarak düzenli morfolojide luminal mide mukoza yapısı yer yer yüzey mukus hücrelerinde deskuamasyon(ok) görülmektedir.

\section{Tartışma}

Bulgularımıza göre overektomi yapılmış SF tedavili sıçanlarda (G2) östrojen seviyesi anlamlı olarak azalmıştır. Serum östradiol düzeyindeki bu düşüş değişmiş gonadal 
hormon durumu doğrulamıştır. Çalışmanın bulguları, cerrahi menopoz gelişimini takiben vücut ağırlığında ortaya çıkan artışın ghrelin tedavisi ile değişmediğini göstermiştir. Periferik yolla verilen ghrelinin gıda alımına etkisi üzerine zıt çalışmalar mevcuttur. Pek çok yayında endojen olarak gıda alımında artışa neden olan ghrelinin, periferik yolla verildiğinde de gıda alımını arttırdığı gösterilmiştir (16-18). Öte yandan yüksek yağlı diyetle beslenen sıçanlarda santral olarak verilen ghrelinin gıda alımını etkilemediği gösterilmiştir (19). Literatürde menopoz sonrası dönemde periferik verilen ghrelinin vücut ağırlığına etkisini gösteren bir çalışma bulunmamaktadır. Ancak obezite ve menopozda serum ghrelin düzeylerinde azalma olduğu rapor edilmiştir (20-22). Çalışmamızda ghrelin tedavisi, menopoz sonrasında zamanla doğru orantılı olarak artan serum ghrelin düzeyindeki düşüşü (22) durdurarak kilo artışını engellemiş olabilir.

Yaşla beraber artan kalsiyum malabsorpsiyonunun düşmüş östrojenle ilişkisi uzun zamandır bilinmekte ve osteoporoz gelişimi açısından bir risk faktörü olarak değerlendirilmektedir (23-26) Kemik mineral yoğunluğu ile atrofik gastriti ilişkilendiren birbirine zıt çalışmalar da mevcuttur $(7,8)$. Ancak bu çalışmalardaki kohort gruplarındaki ırksal farklılıklar dikkat çekicidir. Bulgularımızda, OVT yapılmış sıçanların (G2 ve G3 grupları) midelerinde kısmi olarak dejenerasyonlar görülmüştür. Bulgularımız, menopozun midede atrofiye neden olabileceğini düşündürmektedir.

Bir dizi rapor, ghrelinin in vitro ve in vivo olarak güçlü bir anti-inflamatuvar medyatör ve inflamatuvar hastalıkların ve yaralanmaların tedavisinde umut verici bir terapötik ajan olduğunu tarif etmiştir (27-31). Benzer olarak Helicobacter pylori'nin eşlik ettiği ve etmediği çeşitli atrofik gastrit olgularında serum ghrelin düzeyinde düşüş rapor edilmiştir (32-34). Çalışmamız overektomi ile ortaya çıkan mide hasarının düzeltilmesinde ghrelinin önemli bir rolü olabileceğini işaret etmektedir.

\section{Sonuç}

Sonuç olarak, menopoz sonrasında gözlenen hafif mide inflamasyonunda, ghrelinin koruyucu etkilerinin olduğu gözlenmiştir. Çalışmanın sonuçları, ghrelinin farklı dozlarda ve farklı sürelerde denendiği deneysel çalışmalara ve klinik araştırmalara gereksinimi olduğunu düşündürmektedir.

Etik onam: Bu çalışma için Marmara Üniversitesi Hayvan Deneyleri Yerel Etik Kurulundan onay alındı (06/06/2016 tarih ve 057.2016. mar protokol kodu).

\section{Yazar Katkıları:}

Konsept: E.B.G

Literatür Tarama: E.B.G, Ö.T.Ç.K

Tasarım: E.B.G, D.Ö

Veri toplama: $D$. Ö.

Analiz ve yorum: E.B.G, Ö.T.C.K

Makale yazımı: E.B.G, Ö.T. Ç. K, D.Ö.
Eleştirel incelenmesi: E.B.G

Çıkar Çatışması: Herhangi bir çıkar çatışmamız bulunmamaktadir.

Finansal Destek: Araştırma kapsamında herhangi bir kurum ya da kuruluştan finansal destek sağlanmamıstır.

\section{Kaynaklar}

1. Marcucci G, Brandi ML. Rare causes of osteoporosis. Clin Cases Miner Bone Metab. 2015;12(2):151-6.

2. LaFleur J, Rillamas-Sun E, Colón-Emeric CS, Knippenberg KA, Ensrud KE, Gray SL, et al. Fracture Rates and Bone Density Among Postmenopausal Veteran and Non-Veteran Women From the Women's Health Initiative. The Gerontologist 2016 Feb;56 Suppl 1(Suppl 1):S78-90.

3. Valle J, Kekki M, Sipponen $P$, Ihamäki T, Siurala M. Long-term course and consequences of Helicobacter pylori gastritis. Results of a 32-year follow-up study. Scand J Gastroenterol 1996; 31:546-50.

4. Gazizova RR, Novikova AV, Vinogradova MA. Age-related features of inflammatory and immune responses of the gastric mucosa in women with chronic gastritis. Patol Fiziol Eksp Ter. 1995; 4:32-4.

5. Fotouk-Kiai M, Hoseini SR, Meftah N, Ghadimi R, Bijani A, Noreddini $\mathrm{H}$ et al. Relationship between Helicobacter pylori infection (HP) and bone mineral density (BMD) in elderly people.Caspian J Intern Med. 2015; 6(2):62-6.

6. Heidari B. Helicobacter pylori infection and osteoporosis in elderly patients. Caspian J Intern Med. 2015; 6(2):48-50.

7. Kim HW, Kim YH, Han K, Nam GE, Kim GS, Han BD, et al. Atrophic gastritis: a related factor for osteoporosis in elderly women. PLoS One. 2014; 9(7):e101852.

8. Kakehasi AM, Rodrigues CB, Carvalho AV, Barbosa AJA. Chronic gastritis and bone mineral density in women. Dig Dis Sci 2009,54(4):819-24.

9.Eastell R, Vieira NE, Yergey AL, Wahner HW, Silverstein MN, Kumar R, et al. Pernicious anaemia as a risk factor for osteoporosis. Clin Sci (Lond) 1992;82(6):681-5.

10. Kojima M, Hosoda H, Date Y, Nakazato M, Matsuo H, Kangawa K. Ghrelin is a growth-hormone-releasing acylated peptide from stomach. Nature. 1999 Dec 9;402(6762):656-60.

11. Dass NB, Munonyara M, Bassil AK, Hervieu GJ, Osbourne $S$, Corcoran S, et al. Growth hormone secretagogue receptors in rat and human gastrointestinal tract and the effects of ghrelin. Neuroscience. 2003;120(2):443-53

12. Aydin S, Ozercan IH, Dagli F, Aydin S, Dogru O, Celebi S, et al. Ghrelin immunohistochemistry of gastric adenocarcinoma and mucoepidermoid carcinoma of salivary gland. Biotech Histochem. 2005;80(3-4):163-8.

13. D. DeBoer, M. The Use of Ghrelin and Ghrelin Receptor Agonists as a Treatment for Animal Models of Disease: Efficacy and Mechanism. Current Pharmaceutical Design. 2012;18(31), 4779-99.

14.Granada M, Priego T, Martin Al, Villanua MA, Lopez-Caldoran A. Anti-inflammatory effect of the ghrelin agonist growth hormone-releasing peptide-2 (GHRP-2) in arthritic rats. Am J Physiol Endocrinol Metab 2005; 288: E486-E492.

15. Yukawa M, Weigle DS, Davis CD, Marck BT, Wolden-Hanson T. Peripheral ghrelin treatment stabilizes body weights of senescent male Brown Norway rats at baseline and after surgery. Am J Physiol Regul Integr Comp Physiol. 2008 May;294(5):R1453-60 16. Lippl F, Erdmann J, Steiger A, Lichter N, Czogalla-Peter C, Bidlingmaier $M$, et al. Low-dose ghrelin infusion--evidence against 
a hormonal role in food intake. Regul Pept. 2012; 174(1-3):2631.

17. Nakazato M, Murakami N, Date Y, Kojima M, Matsuo H, Kangawa $\mathrm{K}$, et al. A role for ghrelin in the central regulation of feeding. Nature. 2001;409(6817):194-8.

18.Tschop M, Smiley DL, Heiman ML. Ghrelin induces adiposity in rodents. Nature. 2000; 407:908-13.

19. Briggs DI, Enriori PJ, Lemus MB, Cowley MA, Andrews ZB. Diet-induced obesity causes ghrelin resistance in arcuate npy/agrp neurons. Endocrinology 2010; 151: 4745-55.

20. Álvarez-Castro P, Pena L, Cordido F. Ghrelin in obesity, physiological and pharmacological considerations. Mini Rev Med Chem. 2013;13(4):541-52.

21. Rosická $M$, Krsek M, Matoulek $M$, Jarkovská $Z$, Marek J, Justová $\mathrm{V}$, et al. Serum ghrelin levels in obese patients: the relationship to serum leptin levels and soluble leptin receptors levels. Physiol Res. 2003;52(1):61-6.

22. Karim R, Stanczyk FZ, Brinton RD, Rettberg J, Hodis HN, Mack WJ. Association of endogenous sex hormones with adipokines and ghrelin in postmenopausal women. J Clin Endocrinol Metab. 2014;100(2):508-15.

23. Gallagher J, Riggs BL, Deluca HF. Effect of Estrogen on Calcium Absorption and Serum Vitamin D Metabolites in Postmenopausal Osteoporosis, The Journal of Clinical Endocrinology \& Metabolism. 1980; 51(6):1359-64.

24. Nordin BEC, Need AG, Morris HA, O'Loughlin PD, Horowitz $M$. Effect of age on calcium absorption in postmenopausal women Am J Clin Nutr 2004; 80(4): 998-1002.

25. Heaney RP, Recker RR, Stegman MR and Moy A J. Calcium absorption in women: Relationships to Calcium intake, Estrogen status, and age. J Bone Miner Res 1989; 4: 469-75.

26. Sipponen $P$, Härkönen $M$. Hypochlorhydric stomach: a risk condition for calcium malabsorption and osteoporosis? Scand J Gastroenterol 2009; 45(2):133-8.

27. Zhao $D$, Zhan $Y$, Zeng $H$, Moyer MP, Mantzoros CS, Pothoulakis C. Ghrelin stimulates interleukin-8 gene expression through protein kinase C-mediated NF-kappaB pathway in human colonic epithelial cells. J Cell Biochem. 2006 Apr 15;97(6):131727.

28. Maduzia D, Matuszyk A, Ceranowicz D, Warzecha Z, Ceranowicz $P$, Fyderek $K$, et al. The influence of pretreatment with ghrelin on the development of acetic-acid-induced colitis in rats. J Physiol Pharmacol. 2015;66(6):875-85.

29. De Smet B, Thijs T, Moechars D, Colsoul B, Polders L, Ver Donck $L$, et al. Endogenous and exogenous ghrelin enhance the colonic and gastric manifestations of dextran sodium sulphateinduced colitis in mice. Neurogastroenterol Motil. 2009; 21(1):59-70.

30. Şen LS, Karakoyun B, Yeğen C, Akkiprik M, Yüksel M, Ercan F, et al. Treatment with either obestatin or ghrelin attenuates mesenteric ischemia-reperfusion-induced oxidative injury of the ileum and the remote organ lung. Peptides. 2015; 71:8-19.

31.Cieszkowski J, Warzecha Z, Ceranowicz P. Therapeutic effect of exogenous ghrelin in the healing of gingival ulcers is mediated by the release of endogenous growth hormone and insulin-like growth factor-1. J Physiol Pharmacol. 2017;68(4):609-17.

32. Kalkan Ç, Soykan I. The Relations Among Serum Ghrelin, Motilin and Gastric Emptying and Autonomic Function in Autoimmune Gastritis. Am J Med Sci. 2018;355(5):428-33.

33. Sirchak ES, Patskun SV. Interrelation between ghrelin and gastrin in patients with combination of chronic gastritis and type 2 diabetes mellitus. Wiad Lek. 2018;71(2 pt 1):311-14.
34. Ichikawa H, Sugimoto $M$, Sakao $Y$, Sahara S, Ohashi N, Kato $A$, et al. Relationship between ghrelin, Helicobacter pylori and gastric mucosal atrophy in hemodialysis patients. World J Gastroenterol. 2016; 22(47):10440-49. 